\title{
ANALISIS PENGARUH SIKAP PERCAYA DIRI SISWA DALAM PEMBELAJARAN MATEMATIKA MENGGUNAKAN MODEL PBL BERBANTUAN BAHAN MANIPULATIF
}

\author{
Maria Trisna Sero Wondo ${ }^{1}$, Konstantinus Denny Pareira Meke ${ }^{2}$ \\ ${ }^{1}$ Universitas Flores, Jln. Sam Ratulangi, Ende-Flores-NTT \\ ${ }^{2}$ Universitas Flores, Jln. Sam Ratulangi, Ende-Flores-NTT \\ Email: trisnawondo@gmail.com
}

\begin{abstract}
This study aims to analyze self-confidence using the PBL model assisted by manipulative materials. Sample in this study were students of class VIII SMPK Maria Goretti Ende in the 2019/2020 school year totalling 30 people. This research uses survey and correlational methods. The research instrument was a non-test instrument, namely a questionnaire composed of 20 items based on indicators of self-confidence, namely: 1) self-confidence, 2) assertiveness, 3) responsibility, 4) positive thinking. The results showed that learning mathematics using the PBL model assisted by manipulative materials in class VIII students of SMPK Maria Goretti Ende in the 2019/2020 school year received a positive response where the average student had a high self-confidence indicator of $65.1 \%$.
\end{abstract}

Keywords: Manipulatif Material; PBL; Self-Confidence

\begin{abstract}
Abstrak
Penelitian ini bertujuan untuk menganalisis sikap percaya diri menggunakan model PBL berbantuan bahan manipulatif. Sampel dalam penelitian ini adalah siswa kelas VIII SMPK Maria Goretti Ende tahun pelajaran 2019/2020 berjumlah 30 orang. Penelitian ini menggunakan metode survei dan korelasional. Instrumen penelitian ini adalah instrumen non-tes, yaitu Angket yang disusun terdiri dari 20 item berdasarkan indikator kepercayaan diri yaitu: 1) keyakinan kemampuan diri, 2) ketegasan, 3) betanggungjawab, 4) berpikir positif. Hasil penelitian menunjukkan bahwa pembelajaran matematika menggunakan model PBL berbantuan bahan manipulatif pada siswa kelas VIII SMPK Maria Goretti Ende tahun pelajaran 2019/2020 mendapatkan respon yang positif dimana rata-rata siswa memiliki indikator sikap percaya diri yang tinggi yaitu sebesar $65,1 \%$.
\end{abstract}

Kata kunci:Bahan Manipulatif; PBL; Sikap Percaya Diri

\section{PENDAHULUAN}

Sikap Percaya diri menjadi suatu penilaian afektif yang paling sering dituntut dan diperhatikan dalam pembelajaran matematika. Untuk mencapai kompetensi dan hasil belajar yang baik maka perlu juga diimbangi dengan faktor afektif yang diharapkan dimiliki oleh siswa setelah mempelajari matematika, salah satunya adalah sikap percaya diri. Percaya diri berarti yakin akan kemampuannya untuk menyelesaikan suatu pekerjaan dan masalah. Menurut Azmandian (2010: 145) kepercayaan diri merupakan faktor yang sangat penting dalam kesuksesan seseorang dalam menyelesaikan masalah. Dalam proses pembelajarannya, sikap percaya diri dianggap sebagai suatu tanda siswa mampu dan 
Analisis Pengaruh Sikap Percaya Diri Siswa Dalam Pembelajaran Matematika Menggunakan Model PBL Berbantuan Media Manipulatif

Maria Trisna Sero Wondo ${ }^{1}$, Konstantinus Denny Pareira Meke ${ }^{2}$

Jupika: Jurnal Pendidikan Matematika, Volume 4, Nomor 1. Maret 2021. Hal.11-21

yakin akan solusi yang ditemukan dalam permasalahan yang diberikan (Lintang, Masrukan \& Wardani, 2017: 28).

Suryani \& Gunawan (2018: 189) yang menyatakan bahwa sikap percaya diri merupakan hal yang sangat penting, mengingat sikap percaya diri seharusnya selalu ada pada diri siswa, dimana sikap percaya diri dinilai sebagai sikap positif seorang individu yang memampukan dirinya untuk mengembangkan penilaian positif, baik terhadap diri sendiri, maupun terhadap lingkungan/situasi yang dihadapinya. Kepercayaan diri memengaruhi insentif seseorang untuk melakukan tindakan. Semakin tinggi kemampuan yang dirasakan seseorang dalam suatu kegiatan, semakin kuat pula insentifnya untuk melakukan kegiatan tersebut dan bertahan hingga selesai (Bénabou \& Tirole, 2000).

Agustyaningrum \& Suryantini (2016) dalam hasil penelitiannya menyatakan bahwa terdapat hubungan yang signifikan antara kepercayaan diri dengan hasil belajar matematika siswa. Hal ini dikarenakan bahwa siswa dengan kepercayaan diri yang baik, siswa cenderung optimis akan kemampuan yang dimiliki, aktif menjawab pertanyaan guru serta mengusahakan hasil terbaik. Hal ini berarti siswa yang memiliki kepercayaan diri yang baik akan mendapatkan hasil belajar yang baik pula. Hal ini didukung oleh Ameliah, Munawaroh \& Muchyidin (2016) yang menyatakan bahwa hasil belajar siswa sangat berpengaruh dari faktor yang berasal dari dalam diri salah satunya ialah sikap percaya diri siswa.

Aprisal \& Abadi, (2019: 731) dalam hasil penelitiannya menyatakan bahwa terdapat hubungan yang kuat antara efikasi diri dengan kemampuan komunikasi matematis siswa. Siswa dengan keyakinan dii yang tinggi dapat menguasai semua indikator kemampuan komunikasi matematis. Siswa yang percaya diri, yakin dalam menemukan solusi permasalahan yang diberika guru, karena ia cenderung yakin akan keterampilan dan prinsip yang dimilikinya (Achdiyat \& Lestari, 2016:58). Hal ini menunjukan bahwa rasa percaya diri tentu memberikan reaksi positif terhadap prestasi belajar yang diperoleh siswa. Sebelumnya Vandini (2015: 218) dalam hasil penelitiannya di atas juga menyatakan bahwa kepercayaan diri mempunyai pengaruh yang kuat terhadap prestasi belajar matematika. Prestasi belajar siswa yang baik, didukung oleh kepercayaan diri siswa yang baik pula. Keduanya harus sejalan agar siswa memperoleh peningkatan dalam prestasi belajarnya. Dalam prosesnya, pembelajaran matematika tentu harus dirancang dengan baik untuk memenuhi peningkatan hasil belajar siswa. Pemilihan model pembelajaran menjadi salah satu bagian penting dalam perencanaan pembelajaran. Model pembelajaran yang baik, tidak hanya mampu meningkatkan pengetahuan, namun juga afektif siswa yang berdampak baik pada peningkatan prestasi belajar siswa.

Dalam penerapannya untuk menumbuhkan rasa percaya diri siswa dalam proses pembelajaran di sekolah, diperlukan komitmen yang tinggi baik siswa maupun guru. Hal lain yang sangat penting adalah penerapan model pembelajaran yang mampu melibatkan siswa dalam proses pembelajaran (Ramadhani, 2018:132). Proses pembelajaran yang baik hendaknya menggunakan model pembelajaran yang mampu mendorong siswa untuk terlibat dalam praktik-praktik pembelajaran yang 
Analisis Pengaruh Sikap Percaya Diri Siswa Dalam Pembelajaran Matematika Menggunakan Model PBL Berbantuan Media Manipulatif

Maria Trisna Sero Wondo ${ }^{1}$, Konstantinus Denny Pareira Meke ${ }^{2}$

Jupika: Jurnal Pendidikan Matematika, Volume 4, Nomor 1. Maret 2021. Hal.11-21

berorientasi pada masalah sehari-hari sebagai suatu bentuk aplikasi ilmu dalam hubungannya dengan keseharian siswa (Serafino \& Cicchelli, 2003: 84). Para guru dituntut mampu merancang model pembelajaran yang dapat memotivasi siswa. Hal ini menunjukan kepada siswa atas keseriusan dan bentuk perhatian guru terhadap pelaksanaan pembelajaran di kelas, sehingga diperlukan metode mengajar yang dipandang mampu membangun suasana kelas lebih kreatif dan menarik dan juga tentunya dapat mengatasi kesulitan belajar siswa (Arthur, Oduro \& Boadi, 2014: 669).

Prinsip konstruktivisme dalam pembelajaran matematika menginginkan untuk terlibat secara aktif dalam proses pembelajaran. Menemukan sendiri pengetahuan matematika dengan berbagai sumber daya sebagai alat pembelajaran yang mendukung proses matematisasi sangat dianjurkan dalam proses perencanaan pembelajaran. Alat matematika (model) yang digunakan guru dalam proses pengembangan konsep matematika harus mampu memenuhi tuntutan tersebut (Bito, 2018: 99). Adapun model pembelajaran yang direkomendasikan dalam pengimplementasian kurikulum 2013 yaitu model pembelajaran berbasis masalah (Problem Based Learning). Wondo (2017: 83) menyatakan bahwa model Problem-Based Learning (PBL) mampu meningkatkan kepercayaan diri siswa karena adanya kegiatan pembelajaran yang bermakna, di mana siswa terlibat secara aktif dalam proses diskusi untuk mengidentifikasi masalah, memahami masalah, dan menyelesaikannya dengan memanfaatkan berbagai sumber pengetahuan dan sumber informasi sehingga pada akhirnya memperoleh pengetahuan baru. Kebermaknaan PBL ini sesuai dengan karakteristik dari PBL itu sendiri yang menghadirkan masalah dunia nyata dalam pembelajaran (Meke, Wutsqa \& Alfi, 2018). Jaya, Waluyo \& Siswanto (2019: 414) dalam penelitiannya menyatakan hasil angket siswa tentang sikap percaya diri di atas membuktikan bahwa penerapan model Problem Based Learning (PBL) dapat meningkatkan rasa percaya diri siswa. Hal ini dikarenakan PBL dapat merangsang tumbuhnya kepercayaan diri siswa agar diperoleh hasil belajar yang optimal.

Dalam PBL, siswa terlibat aktif terjadi melalui investigasi kelompok dan kegiatan diskusi. Investigasi kelompok bertujuan untuk menciptakan suasana belajar yang bermakna dan meningkatkan kepercayaan diri siswa, terutama dalam proses pemecahan masalah matematika. Kolaborasi antara siswa, guru dan model pembelajaran yang tepat dapat menciptakan suasana belajar yang kondusif, dan suasana dapat meningkatkan kemampuan matematika siswa, seperti kemampuan pemecahan masalah matematika. Tidak hanya faktor kognitif siswa yang berkembang, tetapi faktor afektif siswa juga dapat mengembangkan rasa percaya diri siswa tersebut (Ramadhani, 2018:132).

Dalam pembelajaran dengan PBL, penyelesaian masalah sering mengalami hambatan akibat bentuk abstrak matematika tabg sulit dituangkan dalam representasi konkrit untuk memudahkan siswa menemukan solusi. Untuk hal tersebut, alat peraga manipulatif dibutuhkan untuk membantu siswa mentransfer objek abstrak matematika, kedalam representasi konkrit. Meke, et. al, (2019) dalam penelitiannya merekomendasikan media pembelajaran berupa alat peraga manipulatif sebagai bantuan dalam proses pembelajaran matematika siswa, agar siswa lebih berminat untuk 
Analisis Pengaruh Sikap Percaya Diri Siswa Dalam Pembelajaran Matematika Menggunakan Model PBL Berbantuan Media Manipulatif

Maria Trisna Sero Wondo ${ }^{1}$, Konstantinus Denny Pareira Meke ${ }^{2}$

Jupika: Jurnal Pendidikan Matematika, Volume 4, Nomor 1. Maret 2021. Hal.11-21

mengikuti proses dan membantu siswa menemukan solusi permasalahan matematika. Selain itu, Niamh O’Meara, Patrick Johnson \& Aisling Leavy (2020) mengungkapkan dalam penelitiannya, bahan manipulatif dapat meningkatkan pemahaman siswa tentang konsep-konsep kunci, meningkatkan sikap siswa terhadap matematika dan membantu siswa dalam membuat hubungan antara matematika dan dunia nyata. . Pandangan positif tentang manipulatif ini, yang dipegang oleh guru bahwa mereka lebih menyukai penggunaan manipulatif di kelas daripada guru pasca sekolah dasar. Pembelajaran Matematika dengan menggunakan alat peraga manipulatif efektif meningkatkan pemahaman konsep siswa (Eriana, Kartono \& Sugianto, 2019:181).

Keefektifan materi manipulatif dalam memfasilitasi pembelajaran ide matematika banyak digunakan untuk merepresentasikan objek abstrak matematika Bahan manipulatif dapat meningkatkan pembelajaran matematika karena mampu menambahkan ide-ide baru ke dalam struktur kognitif mereka (Fennema, 1973) (Golafshani, 2013). Lintang, Masrukan \& Wardani, (2017:28) dalam penelitiannya menggabungkan PBL dengan alat peraga manipulatif dalam pembelajaran matematika mengungkapkan Perangkat pembelajaran PBL dengan APM pada dapat meningkatkan sikap percaya diri siswa karena sintak PBL menuntut siswa untuk aktif baik secara individu maupun kelompok. Guru lebih leluasa untuk mendorong siswa aktif dalam kegiatan pembelajaran.

Mulyani, dkk (2020:111) dalam hasil penelitiannya memadukan pembelajaran PBL dengan penggunaan alat optik, siswa menjadi lebih aktif melalui pembelajaran kolaboratif, sehingga meningkatkan keaktifan dalam mencari dan memecahkan masalah yang diberikan hingga akhirnya memperoleh pengetahuan yang baru. PBL sebagai model pembelajaran yang berpusat pada peserta didik melatih ketrampilan dan kemampuan menyelesaikan masalah. Lebih lanjut Meke \& Wondo (2020: 596) dalam penelitiannya menggunakan model problem based learning menguntungkan siswa untuk aktif dalam proses pembelajaran yang dilaksanakan secara kolaboratif. Penggunaan alat peraga mampu menarik perhatian siswa untuk aktif dalam proses menemukan solusi permasalahan matematika. Hal ini berarti bahwa dengan mengkombinasikan PBL menggunakan alat peraga, hasil belajar yang akan dicapai akan tahan lama diingat siswa, sehingga pelajaran mempunyai nilai tinggi.

Penelitian ini bertujuan untuk menganalisis sikap percaya diri siswa dalam model pembelajaran Problem Based Learning (PBL) dengan penggunaan bahan manipulatif. Peneliti melakukan penelitian mengenai model Problem Based Learning dengan menggunakan bahan manipulatif, untuk membantu siswa menemukan solusi terhadap masalah kehidupan nyata sehari-hari yang diangkat dalam pembelajaran, ditinjau dari sikap percaya diri siswa.

\section{METODE}

Metode dalam penelitian ini adalah metode survei dan korelasional yang bertujuan untuk menganalisis secara mendalam pengaruh sikap percaya diri siswa dalam pembelajaran matematika menggunakan model PBL berbantuan bahan manipulatif. Penelitian ini dilaksanakan di SMPK Maria 
Analisis Pengaruh Sikap Percaya Diri Siswa Dalam Pembelajaran Matematika Menggunakan Model PBL Berbantuan Media Manipulatif

Maria Trisna Sero Wondo ${ }^{1}$, Konstantinus Denny Pareira Meke ${ }^{2}$

Jupika: Jurnal Pendidikan Matematika, Volume 4, Nomor 1. Maret 2021. Hal.11-21

Goretti Ende tahun pelajaran 2019/2020. Populasi dalam penelitian ini adalah siswa kelas VIII SMPK

Maria Goretti Ende. Sampel penelitian adalah siswa kelas VIIIA sebanyak 31 orang.

Instrumen dalam penelitian ini merupakan instrumen non-test, yaitu angket sikap percaya diri siswa sebanyak 20 item berdasarkan indikator kepercayaan diri yaitu: 1) keyakinan kemampuan diri,

2) ketegasan, 3) betanggungjawab, 4) berpikir positif. Pernyataan pada instrumen terdiri atas pernyataan positif dan negatif.

Tabel 1. Pernyataan Positif dan Negatif Skala Sikap Percaya Diri Siswa

\begin{tabular}{|c|c|c|c|c|c|c|}
\hline \multirow{2}{*}{ No } & \multirow{2}{*}{ Pernyataan } & \multicolumn{5}{|c|}{ Respon } \\
\hline & & SL & SR & KD & $\mathbf{J R}$ & TP \\
\hline $\mathbf{A}$ & Indikator Keyakinan Kemampuan Diri & & & & & \\
\hline 1 & $\begin{array}{l}\text { Saya berani menyatakan pendapat dalam diskusi } \\
\text { kelompok }(+)\end{array}$ & & & & & \\
\hline 3 & $\begin{array}{l}\text { Saya yakin dapat menyelesaikan tugas secara mandiri } \\
(+)\end{array}$ & & & & & \\
\hline 9 & $\begin{array}{l}\text { Saya yakin dengan kebenaran jawaban soal ujian } \\
\text { matematika saya }(+)\end{array}$ & & & & & \\
\hline 11 & $\begin{array}{l}\text { Saya lebih senang menyalin jawaban teman ketika } \\
\text { disuruh mengerjakan tugas matematika secara } \\
\text { mandiri (-) }\end{array}$ & & & & & \\
\hline 16 & $\begin{array}{l}\text { Saya merasa tidak akan mendapatkan nilai ujian } \\
\text { matematika yang tertinggi (-) }\end{array}$ & & & & & \\
\hline 20 & $\begin{array}{l}\text { Saya tidak akan mendapatkan nilai matematika yang } \\
\text { bagus sekalipun sudah belajar dengan giat (-) }\end{array}$ & & & & & \\
\hline 2 & $\begin{array}{l}\text { Saya yakin akan berhasil dalam belajar matematika } \\
(+)\end{array}$ & & & & & \\
\hline 17 & $\begin{array}{l}\text { Saya tidak berani untuk mengerjakan soal } \\
\text { matematika di depan kelas, ketika ditunjuk oleh guru } \\
(-)\end{array}$ & & & & & \\
\hline B & Indikator Ketegasan & & & & & \\
\hline 7 & $\begin{array}{l}\text { Saya dapat mempertahankan pendapat yang saya } \\
\text { setujui }(+)\end{array}$ & & & & & \\
\hline 14 & $\begin{array}{l}\text { Saya mudah berubah pikiran ketika berbeda pendapat } \\
\text { dengan teman saat diskusi kelompok (-) }\end{array}$ & & & & & \\
\hline 6 & $\begin{array}{l}\text { Saya berani mengambil sikap dan tidak takut salah } \\
\text { atas keputusan yang saya ambil }(+)\end{array}$ & & & & & \\
\hline 12 & $\begin{array}{l}\text { Saya tidak berani membagikan tugas kepada anggota } \\
\text { kelompok saya, ketika saya dipercayakan sebagai } \\
\text { ketua dalam diskusi kelompok (-) }\end{array}$ & & & & & \\
\hline 13 & $\begin{array}{l}\text { Saya ragu-ragu dalam mengambil keputusan, ketika } \\
\text { saya dipercayakan sebagai ketua saat diskusi } \\
\text { kelompok (-) }\end{array}$ & & & & & \\
\hline $\mathbf{C}$ & Indikator Bertanggung Jawab & & & & & \\
\hline 4 & $\begin{array}{l}\text { Saya bersungguh-sungguh dalam mengerjakan tugas } \\
(+)\end{array}$ & & & & & \\
\hline 18 & $\begin{array}{l}\text { Saya menunda-nunda dalam mengerjakan tugas } \\
\text { matematika yang diberikan guru (-) }\end{array}$ & & & & & \\
\hline 8 & $\begin{array}{l}\text { Saya menyelesaikan tugas kelompok sesuai dengan } \\
\text { waktu yang ditentukan }(+)\end{array}$ & & & & & \\
\hline 15 & Saya tidak mempunyai alasan untuk pendapat yang & & & & & \\
\hline
\end{tabular}


Analisis Pengaruh Sikap Percaya Diri Siswa Dalam Pembelajaran Matematika Menggunakan Model PBL Berbantuan Media Manipulatif

Maria Trisna Sero Wondo ${ }^{1}$, Konstantinus Denny Pareira Meke ${ }^{2}$

Jupika: Jurnal Pendidikan Matematika, Volume 4, Nomor 1. Maret 2021. Hal.11-21

\begin{tabular}{|l|l|l|l|l|l|l|}
\hline & saya ungkapkan ketika diskusi kelompok (-) & & & & \\
\hline D & Indikator Berpikir Positif & & & & \\
\hline 19 & $\begin{array}{l}\text { Saya menjadi malas untuk mengikuti kegiatan } \\
\text { pembelajaran jika materi matematika yang akan } \\
\text { diajarkan sangat sulit menurut saya (-) }\end{array}$ & & & & & \\
\hline 5 & $\begin{array}{l}\text { Saya tetap semangat belajar walaupun materi } \\
\text { matematika sulit (+) }\end{array}$ & $\begin{array}{l}\text { Bagaimanapun nilai matematika yang saya peroleh, } \\
\text { saya berharap dapat bekerja lebih baik pada ulangan } \\
\text { matematika yang akan datang (+) }\end{array}$ & & & & \\
\hline
\end{tabular}

Teknik pengolahan data yang dipakai peneliti adalah dengan menggunakan Microsoft excel. Data skala sikap yang tadinya memiliki nilai ordinal diubah ke dalam bentuk nilai interval menggunakan bantuan method of Succesive Interval (MSI) oleh Microsoft excel. Teknik ini merupakan langkah dalam mengolah skala sikap yaitu seperangkat pernyataan dengan jawaban yang disediakan dan dipilih oleh responden. Penskoran yang digunakan menggunakan skala likert yaitu selalu (SL), sering (SR), kadang-kadang (KD), jarang (JR), tidak pernah (TP). Adapun point dari setiap skala sebagai berikut:

Tebel 2. Point Skala Sikap Percaya Diri

\begin{tabular}{|c|c|c|}
\hline \multirow{2}{*}{ Skala } & \multicolumn{2}{|c|}{ Point } \\
\cline { 2 - 3 } & Positif & Negatif \\
\hline Selalu (SL) & 5 & 1 \\
\hline Sering (SR) & 4 & 2 \\
\hline Kadang-kadang (KD) & 3 & 3 \\
\hline Jarang (JR) & 2 & 4 \\
\hline Tidak Pernah (TP) & 1 & 5 \\
\hline
\end{tabular}

Skala sikap percaya diri digunakan untuk mencari tanggapan dari responden terhadap sikap percaya diri siswa SMPK Maria Goretti Ende dalam pembelajaran matematika menggunakan model PBL berbantuan bahan manipulatif. Data yang telah di dapat untuk dijadikan hasil penelitian sehingga dapat ditarik kesimpulan. Kemudian hasil dari penelitian tersebut diklasifikasikan berdasarkan kriteria presentase skala menurut Riduwan (2007).

Tabel 3. Kriteria Spesifikasi Skala Sikap

\begin{tabular}{|c|l|}
\hline Kriteria (\%) & \multicolumn{1}{|c|}{ Klasifikasi } \\
\hline$N A \leq 20$ & Sangat Rendah \\
\hline $20<N A \leq 40$ & Rendah \\
\hline $40<N A \leq 60$ & Sedang \\
\hline $60<N A \leq 80$ & Tinggi \\
\hline $80<N A \leq 100$ & Sangat Tinggi \\
\hline
\end{tabular}

\section{HASIL DAN PEMBAHASAN}

Penelitian ini dilakukan pada siswa kelas VIII SMPK Maria Goretti Ende tahun pelajaran 2019/2020. Berikut hasil data yang diperoleh dari skala sikap percaya diri siswa. 
Analisis Pengaruh Sikap Percaya Diri Siswa Dalam Pembelajaran Matematika Menggunakan Model PBL Berbantuan Media Manipulatif

Maria Trisna Sero Wondo ${ }^{1}$, Konstantinus Denny Pareira Meke ${ }^{2}$

Jupika: Jurnal Pendidikan Matematika, Volume 4, Nomor 1. Maret 2021. Hal.11-21

Tabel 4. Persentase Skala Sikap Percaya Diri Siswa

\begin{tabular}{|c|c|c|c|c|c|c|}
\hline \multirow[b]{2}{*}{ No } & \multirow[b]{2}{*}{ Indikator } & \multirow{2}{*}{$\begin{array}{c}\text { Banya } \\
\mathbf{k} \\
\text { perny } \\
\text { ataan }\end{array}$} & \multicolumn{3}{|c|}{ Total } & \multirow[b]{2}{*}{$\begin{array}{c}\text { kategor } \\
\text { i }\end{array}$} \\
\hline & & & Skor & Mean & $\%$ & \\
\hline 1 & Keyakinan kemampuan diri & 8 & 768 & 3,2 & 64 & Tinggi \\
\hline 2 & Ketegasan & 5 & 484 & 3,23 & 64,5 & Tinggi \\
\hline 3 & Bertanggung jawab & 4 & 393 & 3,28 & 65,5 & Tinggi \\
\hline 4 & Berpikir positif & 3 & 299 & 3,32 & 66,4 & Tinggi \\
\hline & Total & 20 & 1944 & 13 & 65,1 & Tinggi \\
\hline
\end{tabular}

Dari tabel 4 dapat kita lihat bahwa rata-rata perolehan presentase tiap indikator dengan presentase $65,1 \%$ masuk kedalam kategori tinggi.

Berikut deskriptif statistik visual data sikap percaya diri siswa:

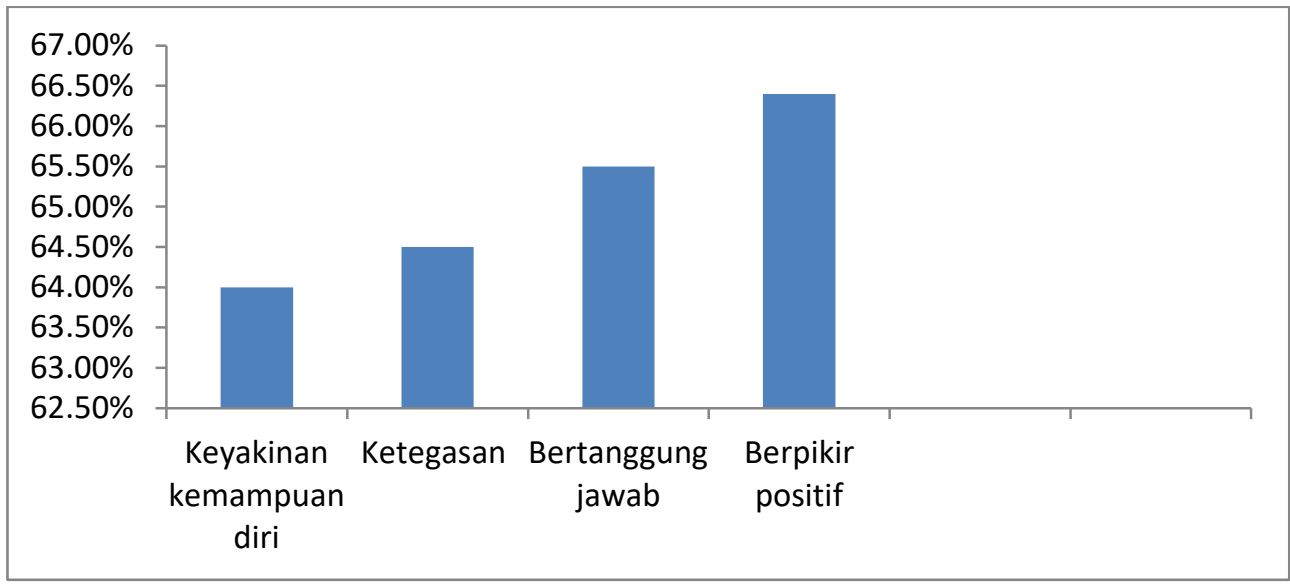

\section{Gambar 1. Diagram Presentase Indikator pada Sikap Percaya Diri Siswa}

Berdasarkan gambar 1 diagram presentase indikator pada sikap percaya diri siswa untuk indikator keyakinan kemampuan diri memperoleh presentase 64\% dengan kategori tinggi, indikator ketegasan memperoleh presentase 64,5\% dengan kategori tinggi, indikator bertanggungjawab memperoleh presentase $65,5 \%$ dengan kategori tinggi, indikator berpikir positif memperoleh presentase $66,4 \%$ dengan kategori tinggi. Indikator berpikir positif mendapatkan presentase yang paling unggul dari indikator lainnya dan semua indikator sikap percaya diri berada dalam kategori tinggi.

Dari data di atas terlihat bahwa rata-rata respon siswa SMPK Maria Goretti Ende pada pembelajaran matematika menggunakan model PBL berbantuan bahan manipulatif memperoleh respon yang positif. Faktor yang mempengaruhi siswa dalam mengikuti pembelajaran dengan hasil yang positif, dikarenakan proses pembelajaran dengan menggunakan model PBL berbantuan bahan manipulatif dirasa lebih variatif dari sebelumnya dan sikap percaya diri siswa semakin tinggi pula. 
Analisis Pengaruh Sikap Percaya Diri Siswa Dalam Pembelajaran Matematika Menggunakan Model PBL Berbantuan Media Manipulatif

Maria Trisna Sero Wondo ${ }^{1}$, Konstantinus Denny Pareira Meke ${ }^{2}$

Jupika: Jurnal Pendidikan Matematika, Volume 4, Nomor 1. Maret 2021. Hal.11-21

Berdasarkan hasil yang diperoleh, dapat disimpulkan bahwa pembelajaran dengan model PBL berbantuan alat peraga manipulatif dinilai efektif dalam meningkatakan sikap percaya diri siswa. Siswa memiliki kepercayaan diri dan motivasi tinggi, Penggunaan model PBL berbantuan alat peraga manipulatif juga dapat meningkatkan motivasi dan keaktifan siswa sehingga rasa percaya diri siswa akan meningkat dan selalu semangat dalam mengikuti proses pembelajaran (Herdini, Suyitno \& Marwoto, 2019: 81). Hasil yang diperoleh ini merupakan akibat dari rasa tertarik siswa selama proses pembelajaran menggunakan bahan manipulatif. Hasil belajar siswa turut mengalami peningkatan karena siswa belajar dengan rasa senang, sehingga rasa percaya diri turut meningkat. Siswa mampu mengolah pemikiran mereka sendiri. Siswa mampu mengatur strategi dan menemukan solusi dari permasalahan yang diberikan (Sakdiyah, 2013: 338-339).

Sikap percaya diri siswa mulai meningkat saat mereka mulai berani memberikan pendapat dalam pembelajaran kolaboratif. Siswa berani dan mulai menghubungkan masalah dengan pengalaman belajar yang diperoleh. Hal ini menunjukan model PBL turut mampu menumbuhkan sikap percaya diri siswa dalam menemukan solusi dari pembelajaran (Rezkillah \& Haryanto, 2020: 265). Peningkatan percaya diri siswa sangat dipengaruhi oleh sintaks pembelajaran PBL yang diantaranya ialah kegaitan siswa dalam menemukan pokok permasalahan dan menemukan bagian penting sebagai kunci dalam menemukan solusi (Hendriana, Johanto \& Sumarmo, 2018:296-297). Lebih lanjut kolaborasi dalam tahapan peneyelidikan antar sesama siswa membuat mereka tidak canggung untuk menyampaikan pendapat masing-masing. Selain itu kesempatan untuk penyajian hasil diskusi tersebut, membuat siswa belajar untuk berani berbicara dan berpendapat (Susanta, Susanto \& Rusdi, 2020:183)

Selain dengan model pembelajaran yang lebih mengutamakan masalah kehidupan nyata siswa, dengan metode kelompok belajar juga memudahkan siswa untuk mendeskripsi dengan baik. Bantuan media manipulatif turut memudahkan siswa untuk bertukar pikiran dan menambah pengetahuan tentang objek yang akan dideskripsikan, sehingga siswa dapat menulis dengan baik (Toja, 2020: 202).

\section{KESIMPULAN}

Pembelajaran matematika menggunakan model PBL berbantuan bahan manipulatif pada siswa kelas VIII SMPK Maria Goretti Ende tahun pelajaran 2019/2020 mendapatkan respon yang positif dimana rata-rata siswa memiliki indikator sikap percaya diri yang tinggi yaitu sebesar $65,1 \%$. Model Problem based learning menggunakan bahan manipulatif mengambil peran yang lebih baik dalam meningkatkan kepercayaan diri siswa. Siswa mendapatkan perlakuan dengan pembelajaran berbasis masalah yang diperoleh pada tingkat nilai yang tinggi. Kesimpulan lainnya adalah siswa lebih aktif dalam keempat tahapan pembelajaran berbasis masalah, lebih kreatif, menunjukkan rasa percaya diri yang cukup baik, lebih mampu berkomunikasi dan bekerja sama dalam memecahkan masalah. Siswa 
Analisis Pengaruh Sikap Percaya Diri Siswa Dalam Pembelajaran Matematika Menggunakan Model PBL Berbantuan Media Manipulatif

Maria Trisna Sero Wondo ${ }^{1}$, Konstantinus Denny Pareira Meke ${ }^{2}$

Jupika: Jurnal Pendidikan Matematika, Volume 4, Nomor 1. Maret 2021. Hal.11-21

menyatakan pendapat yang positif terhadap pelaksanaan pembelajaran. Sementara itu, penggunaan bahan manipulatif sangat berfokus pada persepsi siswa tentang pemahaman dan afektif siswa. Lebih lanjut, penggunaan bahan manipulatif lebih menyoroti manfaat yang dirasakan penggunaan manipulatif dan untuk memotivasi guru untuk terus menggunakan manipulatif sebagai siswa menyeberang dari penggunaan bahan konkrit menuju pada pemikiran abstrak dalam matematika.

\section{DAFTAR PUSTAKA}

Achdiyat, M. \& Lestari, K. D. (2016). Prestasi Belajar Matematika Ditinjau Dari Kepercayaan Diri Dan Keaktifan Siswa di Kelas. Jurnal Formatif. 6(1), 50-61

Agustyaningrum, N. \& Suryantini, S. (2016). Hubungan Kebiasaan Belajar Dan Kepercayaan Diri Dengan Hasil Belajar Matematika Siswa Kelas VIII SMP N 27 BATAM. Jurnal Ilmiah Pendidikan Matematika. 1(2), 158-164

Ameliah, I. H., Munawaroh, M. \& Muchyidin, A. (2016). Pengaruh Keingintahuan dan Rasa Percaya Diri Siswa Terhadap Hasil Belajar Matematika Kelas VII MTs Negeri I Kota Cirebon. EduMa: Mathematics Education Learning and Teaching. 5(1), 9-21

Aprisal, A., \& Abadi, A. (2018). Mathematical communication ability of students viewed from selfefficacy. International Conference on Mathematics and Science Education of Universitas Pendidikan Indonesia, 3, 726-732. $\quad$ Retrieved from http://science.conference.upi.edu/proceeding/index.php/ICMScE/article/view/20

Arthur Y. D, Oduro, F. T \& Boadi. R. K. (2014). Statistical analysis of ghanaian students attitude and interest towards learning mathematics. International Journal of Education and Research 2(6) $661-670$

Azmandian, A. (2010). Think yourself successful. New York, NY: McGraw-Hill Companies, Inc.

Bénabou, Roland \& Tirole, Jean. (2000) Self Confidence: Intrapersonal Strategies. Woodrow Wilson School Working Paper. 209.2 Available at SSRN: https://ssrn.com/abstract=220788 or http://dx.doi.org/10.2139/ssrn.220788

Bito, G. S. (2018). Pemanfaatan Kontribusi Siswa Sebagai Alat Transisi Menuju Pemahaman Konsep Operasi Pecahan. Refleksi Edukatika : Jurnal Ilmiah Kependidikan, 9(1). 90-100

Eriana, E., Kartono, K., \& Sugianto, S. (2018). Understanding Ability of Mathematical Concepts and Students' Self-reliance towards Learning by Implementing Manipulative Props (APM) on Jigsaw Technique. Journal of Primary Education, 8(2), 176-183. Retrieved from https://journal.unnes.ac.id/sju/index.php/jpe/article/view/25984

Fennema, E. (1973). Manipulatif in the classroom. The National Council of Teachers of Mathematics. 20(5), 350-352. https://doi.org/10.5951/AT.20.5.0350.

Golafshani, N. (2013). Teachers' Beliefs and Teaching Mathematics with Manipulatifs. Canadian Journal of Education / Revue canadienne de l'éducation. Vol. 36, No. 3 (2013), pp. 137-159 . https://www.jstor.org/stable/canajeducrevucan.36.3.137

Hendriana, H., Johanto, T. \& Sumarmo, U. (2018). The role of problem-based learning to improve students' mathematical problem-solving ability and self confidence. Journal on Mathematics Education. 9(2), pp. 291-300 
Analisis Pengaruh Sikap Percaya Diri Siswa Dalam Pembelajaran Matematika Menggunakan Model PBL Berbantuan Media Manipulatif

Maria Trisna Sero Wondo ${ }^{1}$, Konstantinus Denny Pareira Meke ${ }^{2}$

Jupika: Jurnal Pendidikan Matematika, Volume 4, Nomor 1. Maret 2021. Hal.11-21

Herdini, R. A., Suyitno, H. \& Marwoto, P. (2019). Mathematical Communication Skills Reviewed from Self-Efficacy by Using Problem Based Learning (PBL) Model Assisted with Manipulatif Teaching Aids. Journal of Primary Education. 8(1), 75-83. https://journal.unnes.ac.id/sju/index.php/jpe/article/view/25311

Kumala, A. J., Waluyo, S. B., \& Siswanto, B. (2019). Implementasi Model Problem Based Learning untuk Meningkatkan Kemampuan Komunikasi Matematis dan Percaya Diri Siswa Kelas X Sma Negeri 4 Semarang. PRISMA, Prosiding Seminar Nasional Matematika, 2, 410-415. Retrieved from https://journal.unnes.ac.id/sju/index.php/prisma/article/view/29024

Lintang, A. C., Masrukan, M. \& Wardani. S. (2017). PBL dengan APM untuk Meningkatkan Kemampuan Pemecahan Masalah dan Sikap Percaya Diri. Journal of Primary Education. 6 (1): $27-34$

Meke, K.D.P., Wutsqa, D.U. \& Alfi, H. D. (2018). The Effectiveness of Problem-based Learning Using Manipulatif Materials Approach on Cognitive Ability in Mathematics Learning. Journal of Physics: Conference Series 1097 (1), 012135

Meke, K.D.P, et, al. 2019. Problem based learning using manipulatif materials to improve student interest of mathematics learning. J. Phys.: Conf. Ser.1157 (032099),1-8.

Meke, K., \& Wondo, M. (2020). Pengembangan Perangkat Pembelajaran Model Problem Based Learning Melalui Penggunaan Bahan Manipulatif. Jurnal Kependidikan: Jurnal Hasil Penelitian dan Kajian Kepustakaan di Bidang Pendidikan, Pengajaran dan Pembelajaran, 6(3), 588-600. doi:https://doi.org/10.33394/jk.v6i3.2861

Mulyani. S., dkk. (2020). Penerapan Model Problem Based Learning Pada Materi Alat-Alat Optik Untuk Meningkatkan Kepercayaan Diri Dan Kemampuan Menyelesaikan Masalah Kontekstual. Jurnal Pendidikan Sains Indonesia (Indonesian Journal of Science Education) 8(1) 105-113.

Niamh O'Meara, Patrick Johnson \& Aisling Leavy (2020) A comparative study investigating the use of manipulatives at the transition from primary to post-primary education, International Journal of Mathematical Education in Science and Technology, 51(6), 835-857, DOI: 10.1080/0020739X.2019.1634842

Ramadhani, R. (2018). The enhancement of mathematical problem solving ability and selfconfidence of students through problem based learning. Jurnal Riset Pendidikan Matematika, 5(1), 127-134. doi:http://dx.doi.org/10.21831/jrpm.v5i1.13269

Rezkillah, I. I. \& Haryanto, H. (2020). Pengaruh Model Pembelajaran Problem Based Learningterintegrasi High Order Thinking Skill Terhadap Kemampuan Berpikir Kritis Dan Sikap Percaya Diri. Jurnal Pendidikan Sains Indonesia (Indonesian Journal of Science Education). $8(2), 257-268$

Sakdiyah, S. H. (2013). Upaya Meningkatkan Pemahaman Tentang Identitas Diri Melalui Pemanfaatan Bahan Manipulatif Siswa Kelas I SD Islam Al Hikmah Gadang Malang. Jurnal Inspirasi Pendidikan, 3(2). 329-341 https://doi.org/10.21067/jip.v3i2.374

Serafino, K. \& Cicchelli, T. (2003). Cognitive Theories, Prior Knowledge, and Anchored Instruction on Mathematical Problem Solving and Transfer. Education and Urban society. 36(1). https://doi.org/10.1177/0013124503257016

Suryani, O. I. \& Gunawan, I. M. (2018). Hubungan Pemahaman Diri dengan Sikap Percaya Diri Pada Siswa Kelas VIII SMPN 7 Woja. Jurnal Kependidikan: Jurnal Hasil Penelitian dan Kajian Kepustakaan di Bidang Pendidikan, Pengajaran dan Pembelajaran. 4(2), 188-191 

Analisis Pengaruh Sikap Percaya Diri Siswa Dalam Pembelajaran Matematika Menggunakan Model PBL Berbantuan Media Manipulatif Maria Trisna Sero Wondo ${ }^{1}$, Konstantinus Denny Pareira Meke ${ }^{2}$ Jupika: Jurnal Pendidikan Matematika, Volume 4, Nomor 1. Maret 2021. Hal.11-21

Susanta, A., Susanto, E. \& Rusdi, (2020). Peningkatan Kepercayaan Diri Mahasiswa dalam Pembelajaran statistika Dasar melalui Problem Based-learning. Jurnal Theorems, 4(2), pp. 179184, doi: $10.31949 /$ th.v4i2.1683.

Toja, D. A. (2020). PENERAPAN PENDEKATAN KONTEKSTUAL MENGGUNAKAN MEDIA GAMBAR UNTUK MENINGKATKAN KETERAMPILAN MENULIS DESKRIPSI PADA SISWA KELAS II SEKOLAH DASAR. Prima Magistra: Jurnal Ilmiah Kependidikan, 1(2), 199-204. https://doi.org/10.37478/jpm.v1i2.642.

Vandini, I. (2015). Peran Kepercayaan Diri Terhadap Prestasi Belajar Matematika Siswa. Jurnal Formatif . 5(3), 210-219.

Wondo, M. (2017). Pengembangan perangkat pembelajaran matematika SMP kelas VIII semester genap dengan model problem-based learning. PYTHAGORAS: Jurnal Pendidikan Matematika, 12(1), 76-86. doi:http://dx.doi.org/10.21831/pg.v12i1.14056 